\title{
Tourist stereotypes and servers' attitudes: a combined theoretical approach
}

\section{Carlos Monterrubio}

To cite this article: Carlos Monterrubio (2018) Tourist stereotypes and servers' attitudes: a combined theoretical approach, Journal of Tourism and Cultural Change, 16:1, 57-74, DOI: 10.1080/14766825.2016.1237518

To link to this article: https://doi.org/10.1080/14766825.2016.1237518

册Published online: 02 Oct 2016.

Submit your article to this journal

LII Article views: 165

Q View related articles $\sqsubset$

View Crossmark data 


\title{
Tourist stereotypes and servers' attitudes: a combined theoretical approach
}

\author{
Carlos Monterrubio
}

Autonomous University of the State of Mexico, Texcoco, Mexico

\begin{abstract}
Local attitudes towards tourism comprise one of the most researched topics in tourism. However, researchers still need to examine attitudes of specific local groups, acknowledge tourist stereotypes as an influential factor and test different theoretical approaches, to develop a broader understanding and explanation of attitudes. Based on an emic perspective, this study analysed servers' stereotypes of a specific group of tourists - locally known as chilangos - and associated attitudes in a Mexican resort. By adopting a combined theoretical approach drawn from social exchange theory and integrated threat theory, this study's results reveal that individuals who depend economically on tourism do not always have positive attitudes and that negative stereotypes on their own are not the strongest predictors of attitudes. By combining both theories' postulations, the findings show that perceived economic benefits and personal positive contact together account for positive attitudes but that these factors are significantly counterbalanced by negative tourist stereotypes. The practical and theoretical implications of these findings are discussed.
\end{abstract}

\section{ARTICLE HISTORY}

Received 1 May 2016

Accepted 12 September 2016

\section{KEYWORDS}

Stereotypes; resident-tourist interaction; local attitudes; tourism servers; chilango; Mexico

\section{Introduction}

From a sociocultural orientation, stereotypes are understood as a social group's set of beliefs about the personal attributes of a different group of people (Ashmore \& Del Boca, 2015). Stereotypes are shaped by individuals' culture and socialising agents. According to Ashmore and Del Boca (2015), individuals are socialised into a particular culture and led to act according to cultural dictates. Therefore, stereotypes support norms about how stereotyped groups and their members are expected to behave and, consequently, how they should be treated. Thus, if expectations are negative, unpleasant or conflictual interactions are likely anticipated (Stephan \& Stephan, 2000). Bearing in mind that tourism affects cultural relations among groups (van den Berghe, 1995), stereotypes may be accentuated or reconstructed as a consequence of local-tourist interactions.

Within the topic of locals and tourists' interactions, little research has been done to understand local residents' tourist stereotypes. These have not been an exclusive focus of research but instead have been incorporated as a quite small component of studies focusing on tourism attitudes. As a result, tourist stereotypes have been explored quite 
superficially. The few existing studies in this vein (Sheldon \& Var, 1984; Var, Kendall, \& Tarakcioglu, 1985; Ward \& Berno, 2011) have examined stereotypes of tourists of different nationalities, using an etic perspective that has not allowed locals to express and explain their tourist stereotypes and attitudes towards tourists based on the locals' own constructs. Thus, studying these stereotypes as a main focus and applying qualitative approaches could be quite useful in generating an understanding of not only what locals' expectations of tourism are but also which, and why, certain attitudes are held by residents in tourism destinations.

Attitudes can be defined as enduring predispositions that are reflected in the way individuals think, feel and behave towards certain phenomena (Getz, 1994). As such, these opinions are structured by cognitive (i.e. knowledge, beliefs and ideas), affective (i.e. likes or dislikes) and conative (i.e. behaviours) components (McDougall \& Munro, 1994). Research on attitudes is quite important as they are strong determinants of individuals' behaviour (Ajzen \& Fishbein, 2005). In the context of tourism impact studies, attitudes may thus be understood as local residents' beliefs, knowledge, feelings of like or dislike and behaviour about - or the intention to act towards - specific aspects of tourism. The latter includes impacts, planning, development, tourists and their behaviour or any other perceived feature of tourism in the locals' environment.

Hitherto, local attitudes towards tourism have been one of the most studied topics in the field. Tourism attitude studies originated in the 1970s (Pizam, 1978; Thomason, Crompton, \& Kamp, 1979). Since then, researchers have examined residents' attitudes in different geographical contexts - with developed countries predominating - and through various theoretical and methodological approaches. Previous findings have consistently shown that residents' positive attitudes are the result of tourism's perceived positive impacts. However, the generalisability of these findings needs to be viewed with caution because, methodologically speaking, most studies have assumed that residents are a homogenous group, and the research has been undertaken in quite specific socio-economic contexts that are not representative of particular local social groups and of other destinations. This has occurred even though empirical research has proved that significant differences exist among different local groups in terms of their attitudes towards tourism (Murphy, 1983). Due to their particular interests, different groups within the same community can be expected to have different attitudes towards tourism and tourists, so these local groups need to be studied separately and in yet unexplored contexts, in order to design more targeted strategies for improving host-guest relations.

As a distinct group within local populations in which local-tourist interactions take place (De Kadt, 1979), servers working in the tourism industry have their specific interests, expectations and experiences. As such, they may have similar intragroup attitudes that are different compared with those other local groups have. In the context of tourism-related social interactions, servers' attitudes play an important role. While positive attitudes lead to more active social relations, according to Reisinger (2009), 'negative attitudes create reservation, suspicion, dissatisfaction and lack of understanding and thus discouragement from the development of interactions ... . [They] often create antagonistic relationships, stereotypes, and prejudices' (p. 208). These will eventually have an effect both on tourist satisfaction and on servers' emotional labour (Anderson, 2006).

Servers have direct contact with tourists, and, therefore, these locals play an important role in defining tourists' experiences. Social interactions between tourists and service 
providers are often reported as being brief, superficial and commercial, but they require servers to be friendly and concerned about service quality (Reisinger, 2009). Positive service encounters largely depend not only on favourable skills, knowledge, personality, performance and behaviour but also on servers' attitudes (Cooper \& Hall, 2008). Positive attitudes can thus lead to many favourable outcomes, including tourists' satisfaction, loyalty and recommendation. Despite the importance of this specific group's attitudes, extremely few studies, if any at all, have focused exclusively on examining servers' tourist stereotypes and attitudes towards tourists. Furthermore, a large number of studies of tourist stereotypes and local attitudes have been atheoretical, leading to a limited understanding and explanation of local-tourist interactions. This problem is further exacerbated in the context of developing countries, including Mexico, in which analyses of host and guest relationships have not been incorporated into general discussions of tourism attitude studies.

To contribute to filling these gaps, the present study sought to analyse perceived tourist stereotypes and their relationship to tourism servers' attitudes in a Mexican resort. Domestic tourists, a sector that has been a largely neglected area in developing countries (Choo, 2016), are the focus of the current study. Incorporating tourism experiences in Mexican contexts into the global debates of tourism studies may help researchers to gain a more comprehensive and socioculturally diverse understanding of local attitudes. Therefore, to develop a more comprehensive understanding and better prediction of service providers' attitudes, this study uses a combined theoretical approach drawn from social exchange theory and integrated threat theory. While both theories have been separately used and proved useful in local attitude studies, each model on its own has been found inadequate to explain and understand fully tourists' stereotypes and related local attitudes. Thus, combined theoretical approaches, such as the one used in this study, may allow a more comprehensive interpretation of tourist stereotypes and local attitudes from different yet combined theoretical perspectives.

\section{Combined theoretical approaches}

One of the main critiques of tourism attitude studies is the lack of theoretical foundations to explain why locals have certain attitudes towards tourism development (Faulkner \& Tideswell, 1997; Haley, Snaith, \& Miller, 2005). Although still limited in volume and contexts, previous research has adopted recognised theories from other disciplines and contributed to advancing theoretical constructions of tourism. Several theories, such as social exchange (Ap, 1990), social representation (Pearce, Moscardo, \& Ross, 1996), social identity (Palmer, Koening-Lewis, \& Medi Jones, 2013), reasoned action (Lepp, 2007), place identity (Wang \& Chen, 2015) and integrated threat (Ward \& Berno, 2011), have been used to explain and predict residents' attitudes from different disciplinary perspectives.

However, each of these theories individually has been, to differing degrees, inadequate on its own to gain a comprehensive understanding of the factors underlying attitudes. For example, social exchange theory may not adequately explain attitudes in relationships in which no exchange between locals and tourists is initiated (Sharpley, 2014), while social representation theory is ambiguous about what social representations actually are. Indeed, researchers have questioned just how useful such representations are (Pearce, 2005). Nonetheless, each theory offers specific valuable postulations that can be used 
to explain attitudes from different perspectives. If the individual strengths and explanatory postulations of these theories are combined and used simultaneously, more fruitful explanations of the underlying factors of attitudes can be expected. Thus, combined theoretical approaches can provide more holistic explanations of tourism attitudes and related issues.

\section{Social exchange theory}

One of the most popular theories in the study of local attitudes is social exchange theory. This theory accounts for both positive and negative tourism impacts as perceived by host communities. According to Ap (1992), social relations involve an exchange of resources among interacting actors, through which they seek mutual benefit. In resident-tourist interactions, the primary motive for initiating exchanges from the residents' perspective is to improve the community and individuals' socio-economic well-being. This theory views local attitudes towards tourism and tourists as a product of the trade-off between benefits and costs, as perceived by local residents. Residents are more likely to be inclined towards, and supportive of, tourism development if they perceive more (i.e. primarily economic) benefits than costs from tourism development (Zhang, Inbakaran, \& Jackson, 2006). Bearing this in mind, Sharpley (2014) postulates that 'the responses of local people to tourists, particularly those engaged in the tourism sector, are more likely to be conditioned by the commercial basis of their encounters with tourists rather than reflecting their actual attitudes towards them' (p. 39).

However, social exchange theory has been criticised for its assumption that humans are isolated individuals and respond like computer information processors (Pearce et al., 1996, p. 34). Therefore, while the theory's principle that those employed in the tourism industry are more supportive of tourism development has been empirically supported (Andriotis \& Vaughan, 2003; Haley et al., 2005; Jurowski \& Gursoy, 2004), not surprisingly, other studies have found evidence that residents who work in the tourism industry do not necessarily react differently from those not employed in the industry (Liu \& Var, 1986).

In this vein, Haley et al. (2005) point out that the existence of exchanges alone does not influence local attitudes, but rather the nature and value of these exchanges. Other factors such as intergroup social and cultural interactions may also influence attitude construction. Of course, how these exchanges are perceived and valued will differ between cultural groups and among group members. Thus, the value attributed to resources will not likely be the same for groups that are economically and culturally different. Due to the complex nature of residents' and tourists' interactions and the varying value attributed to exchanges, social exchange theory needs to be tested further in different sociocultural contexts, including in developing countries and within social groups rarely incorporated in research. Only by testing the postulations of this theory in still unexplored contexts, sociocultural conditions and social groups, can its broad usefulness be further confirmed or challenged.

\section{Integrated threat theory}

Unlike social exchange theory, integrated threat theory has been used in tourism attitude studies quite recently (Monterrubio, 2016; Ward \& Berno, 2011). Its value has been confirmed in the context of international migration (Aberson, 2015; Harrison \& Peacock, 
2010; Rohmann, Florack, \& Piontkowski, 2006; Stephan, Ybarra, Martínez, Schwarzwald, \& Tur-Kaspa, 1998) but not sufficiently tested in the relationships between tourist stereotypes and local tourism attitudes. This theory offers a framework for the study of interactions between groups - in tourism contexts between locals and tourists - and related negative attitudes, on the basis of threats posed by other groups. According to Stephan et al. (1998), integrated threat theory suggests that the degree to which such threats are related to prejudicial attitudes is likely to depend on the type, amount and quality of contact between interacting groups. Therefore, contact plays a particular role in defining intergroup attitudes because contact provides more direct and immediate information about the other groups involved. Individuals whose prior contacts with other groups' members have been predominantly negative are likely to feel threatened by the prospect of future contact with members of these groups (Stephan \& Stephan, 2000).

Integrated threat theory suggests that four major components can significantly explain an in-group's (e.g. locals') attitudes towards other groups: realistic and symbolic threats, intergroup anxiety and negative stereotypes. The first component, realistic threats, is concerned with threats posed by out-groups (e.g. tourists) to the existence of the in-group, commonly arising as a result of competition for resources (e.g. water). The second, symbolic threats, is connected with differences in morals, values, norms, standards and beliefs between the interacting groups. The third, intergroup anxiety, refers to anxiety experienced by the in-group as a consequence of such interactions because of possible negative outcomes. The fourth component, negative stereotypes, is the main interest of this study.

Negative stereotypes are implied threats to in-groups because they lead to unfavourable consequences in the course of interactions. Both culture and socialising agents directly and effectively teach prevailing stereotypes (Ashmore \& Del Boca, 2015). Based on the stereotyping groups' beliefs about the personal attributes of stereotyped groups, these preconceptions create expectations concerning the behaviour of out-group members. Stereotypes play an important role in explaining why certain social groups and their group members are treated in particular ways by other groups. Consequently, to the extent that these preconceptions are negative, conflictual or unpleasant interactions are likely to be anticipated (Stephan et al., 1998). In integrated threat theory, each of the four components can influence attitudes, both individually and in conjunction with other components, but intergroup anxiety and negative stereotypes are better predictors of negative attitudes towards subordinate groups than realistic and symbolic threats are (Stephan et al., 1998). Such postulations, however, have rarely been tested in the context of tourism-related social interactions and even less often in developing countries.

\section{The setting}

In order to meet the objective of this research, the town of Huatulco was selected as a case study. Huatulco is a sea and sun destination located on the Pacific coast in southern Mexico, in the State of Oaxaca. This town is the fifth state-planned destination to be developed in Mexico, a project initiated in 1984 by the federal government, and Huatulco is now one of the most popular resorts for domestic tourists. It has an average annual temperature of $28^{\circ} \mathrm{C}$, and its attractiveness lies in the surrounding mountain landscapes, valleys, a 
national park and, even more importantly, nine bays with sandy beaches. From a microeconomic perspective, this state tourism project sought to create employment, increase public and private investment in the area, foster the agricultural, industrial and construction sectors and improve local residents' quality of life (Orozco, 1992).

In the 2015 list of sea and sun destinations in Mexico, Huatulco ranked eighth in terms of room occupancy (after Riviera Maya, Cancún, Nuevo Vallarta, Los Cabos, Puerto Vallarta, Mazatlán and Cozumel) (SECTUR, 2016). From the beginning, tourism in Huatulco has focused on protection and conservation of the natural environment. Consequently, Huatulco adopted sustainability programmes that established it as one of the first sustainable destinations in the world. In 2005, Huatulco was certified by International Green Globe (now EarthCheck) as the first sustainable tourism community on the American continent. Clean beaches, water treatment, waste recollection and treatment, local natural resources protection and strong community participation in these processes are important features of this destination's sustainability dimension (SECTUR, 2014).

Originally, the project sought to attract international tourist flows mainly from North America (Brenner, 2005). However, Huatulco has always been visited mostly by domestic tourists due to frequent marketing campaigns within the country. In 2014, for example, 92.5\% $(n=520,861)$ of the destination's visitors were Mexicans. Out of these, the vast majority (73\%) came from Mexico City and the State of Mexico (STyDE, 2015). These tourists are referred to as chilangos by local people. In several Mexican provinces, the name chilango is assigned to any person from Mexico City, but its contemporary use is related to an attitudinal attribute of an individual, rather to his place of origin. Chilangos are perceived as aggressive, arrogant, people who are constantly trying to take advantage of others, and even criminals; chilangos' personality thus tends to be used with a sense of complete disdain (Sabates \& Pettirino, 2007). Chilangos are the focus of tourist stereotypes and the present study's analysis of servers' attitudes.

Although the local population originally depended on agriculture and fishing, tourism is now a significant economic and social activity that has contributed to decreased levels of unemployment in the destination (Gullette, 2007). Tourism is currently the most important economic activity. By 2010, an estimated 16, 254 people - almost $50 \%$ of the total population - were either directly or indirectly employed in the sector, particularly in the hospitality and informal commerce sectors (i.e. street and beach vendors) (CONANP, 2003). Tourism activity is mostly concentrated in the neighbourhoods of La Crucecita, Santa Cruz and Tangolunda. Out of these, La Crucecita is the most heavily populated urban area in Huatulco, with a population of 15,130 (INAFED, n.d.). La Crucecita was the main geographical focus of this study as this neighbourhood is the most important localtourist interaction area in the destination. It concentrates most of the services for both tourists and the local population, in general, including food and accommodation establishments, boutiques, banks, transportation, souvenir shops and different types of shops and entertainment services (Figure 1).

\section{Methods}

As mentioned previously, studies of both tourist stereotypes and residents' attitudes towards tourists have mostly adopted etic approaches. In terms of methodology, data have been largely collected using prescriptive lists that researchers have offered to 


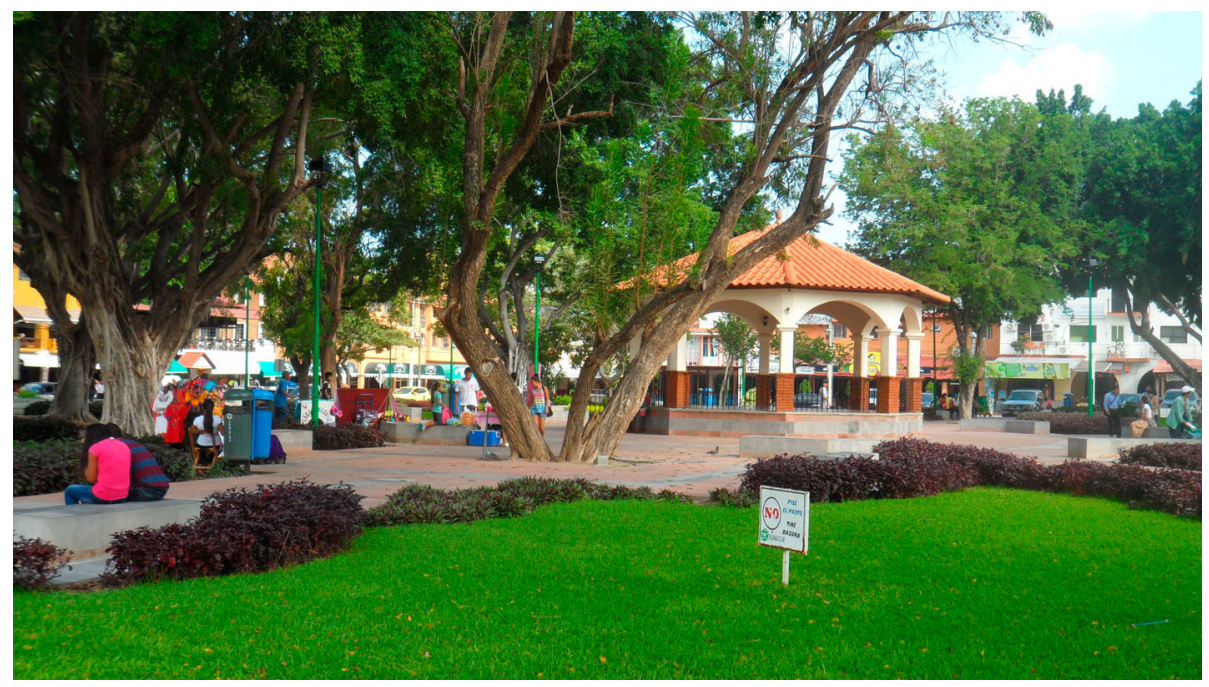

Figure 1. La crucecita city centre (photo taken in 2016).

informants, rather than from researchers listening to the informants' own constructs. In addition, previous research on tourist stereotypes has used quantitative instruments and has largely adopted Likert-type scales. By surveying locals, these studies have identified international tourist stereotypes on the basis of personal attributes such as 'rich', 'poor', 'nice' and 'considerate' (Sheldon \& Var, 1984). Other studies have added residents' stereotypes of domestic tourists and nationals working abroad and have found that domestic tourists are one of the least preferred tourist groups in certain countries (Var et al., 1985). Recent studies have offered informants a wider variety of researchers' predefined responses in questionnaires (e.g. 'rude', 'generous', 'unfriendly', 'clever', 'responsible' and 'respectful') in order to assess stereotypes quantitatively (Ward \& Berno, 2011).

As for tourism attitude studies, the situation is quite similar. They have been restricted to case studies in the so-called developed world, mainly North America, Australia, New Zealand and the UK (Sharpley, 2014). These studies' instruments have also been largely quantitative, and some of them have been designed based on the existing literature or instruments rather than on locals' own descriptions (Haley et al., 2005; Perdue, Long, \& Allen, 1990).

While quantitative methods may be useful in making samples generalisable to broader sections of the population, one of the most important limitations of such approaches is the predetermined character of responses offered by researchers to informants. Therefore, tourist stereotypes and local attitudes in existing quantitative studies may represent only the informants' selection from the researchers' imposed list of predetermined tourists' attributes and local attitudes towards tourists. Most likely, stereotypes and attitudes are heavily influenced by several contextual factors, thus emic approaches are needed if tourists' stereotypes are to be identified from the informants' own experiences and voice. Furthermore, a more in-depth understanding and explanation of community attitudes can be obtained through qualitative methods (Deery, Jago, \& Fredline, 2012). As will be shown below, the qualitative approach used in the present study allowed informants to report their stereotypes and attitudes using their own constructs, which do not necessarily concur with those reported in quantitative studies. 
A qualitative approach with a sample of local tourism servers was adopted for this study. Local servers were selected for this study for three reasons. First, as a quite specific social group depending on tourism, servers are assumed to share similar attitudes. Second, as integrated threat theory suggests, servers' direct, frequent contact with tourists provides immediate information about these visitors, and, thus, stereotypes and attitudes develop more easily. Third, based on social exchange theory, the present study sought to prove that the attitudes of those engaged in the tourism sector are more likely to be conditioned by the commercial basis of their encounters with tourists, in the context of a developing country such as Mexico.

To this end, 51 qualitative interviews were undertaken with local tourist servers in Huatulco, in 2015 (Table 1). The sample comprised participants with different levels of contact with tourists, including, among others, service operators, vendors, handcraft makers, receptionists and waiters. Although the six informants belonging to the Other category did not work for the tourism industry directly, they reported having or having had frequent, direct contact with domestic tourists in some form. Therefore, as integrated threat theory suggests, they also had more immediate information about the stereotyped group (i.e. tourists).

Most interviews were undertaken at the informants' workplace, such as hotels, restaurants, offices, shops, beaches and parks, and the rest took place at informants' houses in La Crucecita. Informants were selected on the basis of convenience and judgement sampling, but a large variety of socio-demographic and service profiles were considered desirable (Table 2). The sample includes a balanced number in terms of gender, and ages ranged from 18 to 62 . One-third of respondents are native to the destination, and the rest were born in other parts of the state or other parts of the country. Over $50 \%$ of participants had resided more than 16 years in the destination, and, on average, they had worked for 12 years in the tourism industry. A relatively long time both residing in the town and working in the industry could help participants to provide more comprehensive perspectives. The vast majority $(92 \%)$

Table 1. Informants' profile: type of server and time in the industry.

\begin{tabular}{|c|c|c|c|c|}
\hline Variables & Categories & Number of informants & $\%^{\mathrm{a}}$ & Mean \\
\hline \multicolumn{5}{|l|}{ Type of server } \\
\hline & Cook & 4 & 7.8 & \\
\hline & Handcraft maker/vendor & 6 & 11.8 & \\
\hline & Receptionist & 5 & 9.8 & \\
\hline & Taxi driver & 2 & 3.9 & \\
\hline & Tour guide & 3 & 5.9 & \\
\hline & Tourist info provider & 2 & 3.9 & \\
\hline & Tourist service operator & 11 & 21.6 & \\
\hline & Waiter/waitress & 3 & 5.9 & \\
\hline & Vendor & 9 & 16.6 & \\
\hline & Other $^{\mathrm{b}}$ & 6 & 11.8 & \\
\hline \multirow[t]{6}{*}{ Time working in the tourism industry (years) } & & & & 12 \\
\hline & $0-5$ & 19 & 37.3 & \\
\hline & $6-10$ & 10 & 19.6 & \\
\hline & $11-15$ & 5 & 9.8 & \\
\hline & $16-20$ & 5 & 9.8 & \\
\hline & Over 20 & 12 & 23.5 & \\
\hline
\end{tabular}

${ }^{\mathrm{a}}$ Due to rounding, percentages do not total $100 \%$.

bother includes computer technician, graphic designer, litter collector, chemist's clerk, constructor and street singer. 
Table 2. Informants' profile: socio-demographics and contact with tourists.

\begin{tabular}{llccc}
\hline Variables & \multicolumn{1}{c}{ Categories } & Number of informants & $\%^{\text {a }}$ & Mean \\
\hline Gender & Female & 25 & 49 & \\
& Male & 26 & 51 & 36 \\
Age (years) & $18-27$ & 16 & 31.4 & \\
& $28-37$ & 15 & 29.4 \\
& $38-47$ & 10 & 19.6 \\
& Over 48 & 10 & 19.6 \\
Place of birth & Huatulco & 16 & 31.4 \\
& Other city/town within Oaxaca & 18 & 35.3 & \\
& Other state in Mexico & 17 & 33.3 & 17 \\
Time living in destination (years) & & & & \\
& $0-5$ & 12 & 23.5 & \\
& $6-10$ & 6 & 11.8 & \\
& $11-15$ & 5 & 11.8 & \\
& $16-20$ & 6 & 43.1 & \\
Contact with tourists & Over 20 & 22 & 74.5 & \\
& Everyday & 38 & 7.6 & \\
\hline
\end{tabular}

${ }^{a}$ Due to rounding, percentages do not total $100 \%$.

live in the destination and, although half of them have previously worked in the tourism industry, most of them have not received any special tourism education or training.

The interview guide was made up of four sections. Largely based on the open-ended question, 'What are chilango tourists like?', the first section aimed to identify tourist stereotypes. The second section sought to determine the tourists' profile (e.g. activities, length of stay, preferred accommodation and food places and means of transportation). The third aimed to identify tourism impacts and local attitudes. Regarding the latter, special attention was paid to the explicit affective dimension of attitudes by asking, 'Do you like or dislike chilango tourists?' The final section gathered servers' socio-demographic data: age, type of service provided, time working in the tourism industry and, quite importantly, the type and frequency of contact and personal experiences with this type of tourist. With the informants' consent, all interviews were tape-recorded for analysis.

Bearing in mind that the processes of qualitative data analyses rarely are rigorously examined (Sandiford \& Seymour, 2007), special care was taken in the interview analyses. Each interview was first analysed and interpreted independently. The informants' stereotypes, attitudes and perceived tourism impacts were extracted from each interview. While stereotypes were identified on the basis of tourists' reported personal attributes, tourism impacts were identified on the basis of perceived benefits and costs, and attitudes were extracted from the informants' stated personal likes or dislikes associated with tourists. Next, descriptions referring to tourist stereotypes were grouped on the basis of domains that grouped similar meanings attributed by informants. In order to corroborate the use of both social exchange theory and integrated threat theory, the relationships were examined between servers' perceived resource exchange and attitudes, as well as server-tourist contact and stereotypes. 


\section{Findings}

\section{Server-tourist contact}

The frequency of servers' contact with tourists is reported in Table 2. As can be seen, almost three-quarters of informants have contact with chilango tourists every day. According to integrated threat theory, the amount of contact is important - as is the nature of intergroup contact - in defining intergroup attitudes. Therefore, the fact that servers' contact with tourists in Huatulco is very frequent will influence locals' attitudes. Stephan and Stephan (2000) claim that the more positive the contact, the lower the threat perceived by in-groups. For the study in question, most servers interviewed report their contact with tourists as positive. Most importantly, perhaps, more intimate relationships have developed, for several interviewees, out of initial resident-tourist commercial exchanges. This is the case mainly with repeated visitors to the destination. Notably, frequent and repeat visits are a dominant characteristic of domestic tourism (Choo, 2016). Informant 5, a woman who has worked as a waitress, said, 'Many families have returned to Huatulco and we have developed positive and trustworthy relations.' Similarly, informant 38 , a handcraft vendor working for 30 years in the tourism sector with everyday contact with tourists, shared her experience this way:

There was a couple who visited Huatulco for the first time 20 years ago. They were dating back then. They are married now and have an eleven-year-old child. They keep coming year after year, and, when they come, we talk, we go out. We have become sort of relatives.

Informant 34, a 49-year-old man working as an aquatic tour provider, said something similar. 'I had the chance to visit them [tourists] in Mexico City. Some tourists have become my friends, and we keep in frequent touch by phone.' Supporting the idea that servers' contact with tourists is not necessarily brief, superficial and commercial, some servers recognise that such interactions are more than economic transactions. Informant 39 , a 21-year-old female handcraft vendor who has always resided in the destination reported, 'We have spent time with chilangos. In fact, one of them has become like part of our family. His sister is now my godmother. Our relationship goes beyond the commercial level.' Clearly, negative intergroup contact has taken place, but positive experiences have predominated, in general, and often go beyond commercial encounters. As seen in the next subsection, this has relevant implications that shape servers' attitudes towards tourists.

\section{Tourists' stereotypes}

Servers' tourist stereotypes were identified by analysing each interview on the basis of tourists' attributes as reported by informants. While qualitative methods allow richly detailed descriptions, a difficulty created for analysis is categorising informants' responses. In the present study, domains were constructed by grouping informants' descriptions that basically referred to the same tourist personal attribute. Thus, adjectives, descriptions and examples were all useful for grouping attributes into domains. By doing this, stereotypes were presumably obtained in the informants' own voice.

Based on the number of informants who reported the same stereotype domain, as well as on the relevance that such attributes represented for informants, three major 
stereotypes were identified (Table 3). Relevance was assessed based on the detailed descriptions, examples, reported feelings and frequency with which attributes were mentioned by each informant. Clearly, the most dominant tourist stereotype is that they are dirty. The greatest number of informants (82.3\%) were concerned about not only the amount of trash generated by chilangos but also the way this was left in public places. Informant 36, a female taxi stop operator in contact with tourists every day, argued, 'Chilangos leave a lot of trash, yes, too much trash. They throw it everywhere. They do not put it in containers.' In servers' mind, this is a particular characteristic of chilango tourists as compared with other tourists. Informant 12, a native-born cook living in the destination for 28 years, observed that 'many tourists put their trash into containers, but chilangos throw it anywhere. They don't care'. Arguably, this particular characteristic has been reported by other writers as a general characteristic of chilangos (Conti \& Basave, 2013). The significance of this stereotype may be explained on the basis of the destination's cleanliness, which has been recognised by international tourists visiting the town (Cuellar-Rio \& Kido-Cruz, 2008).

The second most dominant tourist stereotype is that they seek low prices. Bearing in mind that commercial transactions are the main type of server-tourist encounters, servers clearly have much to say about these relationships. According to the far greater majority of informants (74.5\%), chilangos are characterised by always looking for cheap places at which to stay and eat. Bargaining is a widely identified attribute of these tourists since they frequently try to get reduced prices in accommodation, food, recreational services and other products, such as souvenirs. Travelling in large groups by hired buses and bringing their own food is also a way tourists reduce costs. This type of tourist is, therefore, stereotyped as spending the least possible money. Informant 27, a tour guide originally from the State of Mexico, explained it this way:

Most of these tourists are used to bargaining. They stay in the cheapest hotel possible and try to get four or five people into a single room in order to save money .... It is a very poor type of tourism. They come by their rented bus, buy groceries at the local store and cook their own food on the streets or on the beach.

In general, both being dirty and seeking low prices are both regarded as unfavourable characteristics of tourists. Since negative stereotypes are one of the strongest and most consistent predictors of negative attitudes (Stephan et al., 1998), these stereotypes may be quite relevant for understanding servers' negative attitudes towards chilangos.

Table 3. Servers' tourist stereotypes.

\begin{tabular}{lcr}
\hline Stereotype & Number of informants & $\%$ \\
\hline Dirty & 42 & 82.3 \\
Seeking low prices & 38 & 74.5 \\
Friendly/sociable & 27 & 52.9 \\
Boisterous/disrupt public order & 20 & 39.2 \\
Aggressive/rude/vulgar & 16 & 31.3 \\
Partiers/fun seekers & 12 & 23.5 \\
Feeling superior to locals & 10 & 19.6 \\
Kind & 9 & 17.6 \\
Stealing & 7 & 13.7 \\
Disrespectful/unkind & 5 & 9.8 \\
Demanding & 5 & 9.8 \\
Open-minded & 3 & 5.8 \\
\hline
\end{tabular}


The top-third stereotype was a positive characteristic according to servers: being friendly and sociable. This attribute was described by over half of the informants. They claimed that these tourists like talking, socialising, meeting local people and making new friends; this was clearly an acceptable characteristic of chilangos. As mentioned above, some interactions have become, in the informants' own words, true friendships between locals and tourists.

Naturally, servers have other tourist stereotypes, but they are not as dominant as the ones described above either in terms of the frequency reported (less than $50 \%$ of informants) or in the significance reported by informants. What is important to note, however, is that out of the nine stereotype domains remaining, six are regarded as negative: being boisterous and disrupting the public order, being aggressive and rude, feeling superior to locals, stealing things from locals and other tourists, being disrespectful and being demanding. Enjoying partying, being kind and being open-minded were attributes regarded as positive. Notably, out of the 12 stereotype domains identified, nine were perceived by informants as negative characteristics of tourists. This supports the conclusion that most stereotypes of domestic tourists (i.e. chilangos) in the destination studied are negative, possibly generating relevant implications for servers' prejudicial attitudes - if integrated threat theory postulations are regarded as applicable in this study.

\section{Servers' attitudes}

As stated previously, the servers' attitudes were assessed in their affective dimension, but cognitive components were indirectly identified through stereotypes. If social exchange theory's postulations are also applicable, the servers studied would be expected to have positive attitudes. However, as Table 4 reveals, only a little over half of the informants (52.9\%) clearly reported having a positive attitude, while over $31 \%$ reported indifference. They neither liked nor disliked such tourists. Notably, five interviewees were aware of holding both positive and negative attitudes simultaneously, and three overtly stated that they have negative attitudes. Negative attitudes were largely associated with tourist unfavourable stereotypes. Although many servers' attitudes towards tourists in the destination are positive, special attention needs to be paid to how those who hold neutral attitudes (31.3\%) can develop negative prejudices, and, thus, together with those having both positive and negative (9.8\%) and only negative (5.8\%) attitudes, these servers may comprise all together almost half of the population studied. In other words, almost half of the servers may potentially have negative attitudes towards domestic tourists. This has some practical implications for reducing negative relations between servers' and chilangos. However, this study's sample is not representative of the whole server population, and these findings can only function as indicative of problematic tendencies.

Table 4. Servers' attitudes towards tourists.

\begin{tabular}{lcr}
\hline Attitude & Number of informants & $\%^{\mathrm{a}}$ \\
\hline Like & 27 & 52.9 \\
Neutral & 16 & 31.3 \\
Both like and dislike & 5 & 9.8 \\
Dislike & 3 & 5.8 \\
\hline
\end{tabular}

${ }^{\mathrm{a} D u e}$ to rounding, percentages do not total $100 \%$. 
Based on informants' arguments, narrations and examples, servers' attitudes are postulated to be shaped by three main factors: economic benefit, contact and personal experiences, and tourist stereotypes. The association of these factors was evidenced in each type of attitude. For positive attitudes, for example, both previous contact and economic benefits were observed to be equally important. Informant 2, a male tour guide in contact with domestic tourists every day, acknowledged this by saying, 'I like tourists ... That is because I haven't had any unpleasant experiences with tourists and because tourists bring money that I can take home.' Showing that different positive and negative factors interact in neutral attitudes, Informant 25 , a receptionist in contact with tourists every day who reported all her experiences with tourists as positive, shared her perspective as follows: 'Tourists are noisy, disrespectful and damage hotel facilities ... but, personally, all my experiences with them have been positive.... Although they look for cheap prices, they create jobs for us.'

This study's findings, thus, suggest that attitudes are shaped significantly by these three factors. Economic benefits may lead to contact, positive attitudes and experiences and stereotypes - whether positive or negative - and may strengthen positive or create negative local predispositions. The outcome of such attitudes is likely to depend on the significance individuals give to these factors and the way these are negotiated on a personal level. This postulation supports the idea that it is not only the existence of exchanges alone that influences local attitudes but also the nature and value of such exchanges (Haley et al., 2005).

\section{Discussion of findings}

This study analysed stereotypes of a specific segment of domestic tourism and their relationship to servers' attitudes in a Mexican resort. In order to get a more comprehensive explanation of local attitudes, this research embraced a combined theoretical approach, adopting both social exchange theory and integrated threat theory. Based on this combined perspective, the results reveal that attitudes are not only explained by perceived exchanges, as social exchange theory suggests. Servers' attitudes are likely to be significantly shaped by three main variables, both positive and negative. These are locals' perceptions of resource exchanges (i.e. economic benefit), the amount and type of contact and tourist stereotypes.

Social exchange theory accounts primarily for the importance of economic benefit. Thus, this study partly confirms this postulation. While the findings show that those with economic benefits from tourism will hold positive attitudes, the results also reveal that even individuals who depend economically on tourism do not always hold positive attitudes. This is not only because the nature and value of social exchanges matter, but also because other significant factors intervene in attitude formation. From an integrated threat theory perspective, previous contact and experiences are also significant predictors of attitudes, and they can counterbalance or reinforce positive attitudes derived from resource exchange. In addition to perceived economic benefits, positive contact can lead to positive attitudes and, thus, strengthen positive attitudes derived from perceived financial benefits. According to integrated threat theory, the amount and quality (i.e. positive or negative) of contact affect feelings of threat: the greater the frequency of positive contacts relative to negative contacts, the lower the threat (Stephan \& Stephan, 2000). 
Based on the present study's findings, servers whose prior contact with tourists has been predominantly positive are likely to develop favourable attitudes and/or become increasingly convinced of perceived economic benefits.

In addition, this study partly corroborates that negative stereotypes, as suggested by Stephan et al. (1998), are also significantly influential factors in attitudes. In the present research, most stereotypes were found to be negative, but attitudes were mostly positive. Thus, stereotypes are not necessarily the best predictors of attitudes, yet they definitely play an important role. In this way, stereotypes can considerably counterweigh positive attitudes arising from resource exchange and favourable contact. How final attitudes are defined, constructed and negotiated are likely to depend on the significance that individuals assign to these resources, the value of personal experiences with tourists, and the way the perceptions of tourists as a group are constructed in people's minds (i.e. stereotypes). This study's results highlight the need to recognise that the understanding of local attitudes, even within social groups economically dependent on tourists (e.g. servers), must go beyond exchanges of resources, demanding consideration of a broader variety of variables. These necessarily include tourist-resident contact and tourist stereotypes.

Thus, combining the individual strengths and explanatory postulations of both social exchange and integrated threat theories offers a more comprehensive explanation of the underlying factors of attitudes. While social exchange theory on its own can explain the value of economic benefits in defining positive attitudes, the addition of integrated threat theory helps to identify other factors, such as positive contact, that can strengthen positive attitudes, as well as showing how negative stereotypes may potentially counterweigh positive predispositions. Therefore, a conceptual model that simultaneously considers resource exchanges and the amount and nature of contacts and stereotypes has a greater potential for explaining and understanding tourism attitudes. In short, combined theoretical approaches can help to gain a deeper comprehension of these and other factors likely to affect local attitudes.

A final issue that deserves discussion is the nature of intra- and intergroup relations in tourism. Researchers have postulated that intimate relationships in tourism can take place either among locals or among tourists (i.e. intragroup intimacy) (Trauer \& Ryan, 2005). However, although local-tourist interactions are often believed to be brief and superficial, intimate relationships can also develop between residents and tourists (Woosnam, 2011). The present study's results strengthen the viewpoint that personal relationships between servers and tourists are often oversimplified. Based on the empirical evidence provided here, contact between servers and tourists is not always as superficial as believed. Intimate personal relationships can develop from interactions that initially served commercial purposes. As such, server-tourist relations can become significantly more influential than other factors such as resource exchange in defining local attitudes towards tourists. Quantitative correlational studies, however, are needed to confirm this hypothesis.

\section{Conclusion and implications}

This study adopted a combined theoretical approach to understand and explain how servers' attitudes are constructed. The findings support the conclusion that the combination of different theories - in this research, social exchange and integrated threat - 
provides more potential for explaining and understanding why individuals who depend economically on tourism do not always have positive attitudes towards tourists. This approach also clarifies why those who develop negative stereotypes do not necessarily have negative attitudes. In the case of servers, positive contact and experiences with tourists can lead to, or strengthen, existing positive attitudes, but servers' negative stereotypes are likely to counterbalance the final outcome in terms of attitudes. Nonetheless, the results reveal that personal positive contact and perceived economic benefits appear to dominate as compared with negative stereotypes. In short, personal positive experiences with tourists and perceived economic benefits seem to be more influential in defining attitudes when compared with negative cognitive dimensions (i.e. stereotypes).

This study has important practical implications for the tourism industry. Of particular relevance are the implications for servers. Quite likely, some servers, despite having a negative attitude, have to pretend that they provide friendly services; they need to 'perform' what is called emotional labour. Informant 48, a waitress interacting with tourists every day and revealing both positive and negative attitudes, declared, 'I sometimes don't like chilangos ... but it's my job, so I have to treat them well because my family depends on them.' Emotional labour can have negative effects; it results from a misfit between true emotions and reality in the job. It can lead to servers' exhaustion, distress, decreased motivation and the development of dysfunctional attitudes and behaviours at work (Anderson, 2006). At a more individual level, emotional labour can lead to what is called cognitive dissonance. This takes place when individuals, for different reasons, behave in a way that is not consonant with their beliefs and attitudes (Woods, 2016). This can take its toll on servers' psyche, producing emotional distress and, ultimately, lowering service quality and poor productivity.

Conversely, diminishing negative stereotypes also is necessary if more satisfactory experiences for both tourists and servers are expected. According to Reisinger (2009), 'Any contact which is transitory, superficial, unequal and subjected to exploitation, mistrust, and stereotype formation does not provide any opportunity for engaging in a meaningful interaction' (p. 206). Thus servers' negative stereotypes, although not always as strong as a predictor of attitudes as other factors are, should also be a matter of concern for the industry. Eliminating negative stereotypes can enhance social relations between servers and tourists and, consequently, tourists' experiences.

The present study's findings and propositions need to be treated with caution. Although the sample size of this research was larger than that of other qualitative studies (see, e.g. Brunt \& Courtney, 1999; Cooke, 1982; Lepp, 2007), the results should not be generalised to the rest of the studied locality's residents or to other populations. This study can be considered only an illustrative case, and, thus, the findings are applicable to the sample selected for this research. This limitation could undoubtedly be overcome by applying quantitative methodological approaches that can obtain representative samples and, therefore, more generalisable results. Future research paths can be found by considering the attitudes of beach vendors in the destination. Beach vendors are a quite ubiquitous group in many destinations in Mexico. Due to their particular socio-economic conditions, including informal self-employment, low levels of education and exclusion from dominant capitalist models of tourism (Wilson, 2012), beach vendors have also much to say about tourists. 


\section{Acknowledgements}

The author would like to express his deepest gratitude to Luis Valencia for his invaluable support in this study.

\section{Disclosure statement}

No potential conflict of interest was reported by the author.

\section{ORCiD}

Carlos Monterrubio (D) http://orcid.org/0000-0002-3706-4644

\section{References}

Aberson, C. L. (2015). Positive intergroup contact, negative intergroup contact, and threat as predictors of cognitive and affective dimensions of prejudice. Group Process \& Intergroup Relations, 18(6), 743-760.

Ajzen, I., \& Fishbein, M. (2005). The influence of attitudes on behavior. In D. Albarracín, B. T. Johnson, \& M. P. Zanna (Eds.), The handbook of attitudes (pp. 173-221). Mahwah, NJ: Erlbaum.

Anderson, B. (2006). Emotional labour and coping strategies. In B. Prideaux, G. Moscardo, \& E. Laws (Eds.), Managing tourism and hospitality services: Theory and international applications (pp. 170180). Oxfordshire: CABI.

Andriotis, K., \& Vaughan, R. D. (2003). Urban residents' attitudes toward tourism development: The case of Crete. Journal of Travel Research, 42(2), 172-185.

Ap, J. (1990). Residents' perceptions research on the social impacts of tourism. Annals of Tourism Research, 17(4), 610-616.

Ap, J. (1992). Residents' perceptions on tourism impacts. Annals of Tourism Research, 19(4), 665-690.

Ashmore, R. D., \& Del Boca, F. K. (2015). Conceptual approaches to stereotypes and stereotyping. In D. L. Hamilton (Ed.), Cognitive processes in stereotyping and intergroup behavior (pp. 1-35). New York, NY: Psychology Press.

van den Berghe, P. L. (1995). Marketing Mayas. Ethnic tourism promotion in Mexico. Annals of Tourism Research, 22(3), 568-588.

Brenner, L. (2005). State-planned tourism destinations: The case of Huatulco, Mexico. Tourism Geographies, 7(2), 138-164.

Brunt, P., \& Courtney, P. (1999). Host perceptions of sociocultural impacts. Annals of Tourism Research, 26(3), 493-515.

Choo, H. (2016). Domestic tourism. In J. Jafari \& H. Xiao (Eds.), Encyclopedia of tourism (pp. 267-268). New York: Springer International Publishing.

CONANP. (2003). Programa de Manejo Parque Nacional Huatulco [Huatulco National Park Management Programme]. Mexico: Author.

Conti, N., \& Basave, D. (2013). El libro chilango. Actitudes, amores y odios de los hermosos habitantes del DF [The chilango book. Attitudes, loves and hates of the beautiful inhabitants of Mexico City]. Mexico: Planeta.

Cooke, K. (1982). Guidelines for socially appropriate tourism development in British Columbia. Journal of Travel Research, 21(1), 22-28.

Cooper, C., \& Hall, C. M. (2008). Contemporary tourism: An international approach. London: Butterworth-Heinemann.

Cuellar-Rio, M., \& Kido-Cruz, M. T. (2008). Perfil y análisis del gasto del crucerista: El caso de Bahías de Huatulco (México) [Cruise passengers' expenditure profile and analysis: The case of Huatulco bays (Mexico)]. Cuadernos de Turismo, 22, 47-78.

Deery, M., Jago, L., \& Fredline, L. (2012). Rethinking social impacts of tourism research: A new research agenda. Tourism Management, 33(1), 64-73. 
De Kadt, E. J. (1979). Tourism - passport to development? Perspectives on the social and cultural effects of tourism in developing countries. Oxford: Oxford University Press.

Faulkner, B., \& Tideswell, C. (1997). A framework for monitoring community impacts of tourism. Journal of Sustainable Tourism, 5(1), 3-28.

Getz, D. (1994). Residents' attitudes towards tourism: A longitudinal study in Spey Valley, Scotland. Tourism Management, 15(4), 247-258.

Gullette, G. S. (2007). Migration and tourism development in Huatulco, Oaxaca. Current Anthropology, 48(4), 603-611.

Haley, A., Snaith, T., \& Miller, G. (2005). The social impacts of tourism: A case study of Bath, UK. Annals of Tourism Research, 32(3), 647-668.

Harrison, N., \& Peacock, N. (2010). Cultural distance, mindfulness and passive xenophobia: Using integrated threat theory to explore home higher education students' perspectives on 'internationalisation at home'. British Educational Research Journal, 36(6), 877-902.

INAFED. (n.d.). Enciclopedia de los Municipios y Delegaciones de México. Estado de Oaxaca. Santa María Huatulco. [Encyclopaedia of municipalities and delgations in Mexico. Oaxaca State. Santa María Huatulco]. Retrieved July 7, 2016, from http://www.inafed.gob.mx/work/enciclopedia/ EMM20oaxaca/municipios/20413a.html

Jurowski, C., \& Gursoy, D. (2004). Distance effects on residents' attitudes toward tourism. Annals of Tourism Research, 31(2), 296-312.

Lepp, A. (2007). Residents' attitudes towards tourism in Bigodi village, Uganda. Tourism Management, 28(3), 876-885.

Liu, J. C., \& Var, T. (1986). Resident attitudes toward tourism impacts in Hawaii. Annals of Tourism Research, 13(2), 193-214.

McDougall, G., \& Munro, H. (1994). Scaling and attitude measurement in travel and tourism research. In B. Ritchie \& C. R. Goeldner (Eds.), Travel, tourism, and hospitality research: A handbook for managers and researchers (pp. 115-129). New York, NY: John Wiley and Sons.

Monterrubio, C. (2016). The impact of spring break behaviour: An integrated threat theory analysis of residents' prejudice. Tourism Management, 54, 418-427.

Murphy, P. (1983). Perceptions and attitudes of decisionmaking groups in tourism centers. Journal of Travel Research, 21(3), 8-12.

Orozco, P. (1992). Bahías de Huatulco: Reseña de la reubicación [Huatulco bays: Relocation history]. ALTERIDADES, 2(4), 95-99.

Palmer, A., Koening-Lewis, N., \& Medi Jones, L. E. (2013). The effect of residents' social identity and involvement on their advocacy of incoming tourism. Tourism Management, 38, 142-151.

Pearce, P. (2005). Tourist behaviour: Themes and conceptual schemes. Clevedon: Channel View Publications.

Pearce, P., Moscardo, G., \& Ross, G. (1996). Tourism community relationships. Oxford: Elsevier Science.

Perdue, R., Long, P., \& Allen, L. (1990). Resident support for tourism development. Annals of Tourism Research, 17(4), 586-599.

Pizam, A. (1978). Tourism's impacts: The social costs to the destination community as perceived by its residents. Journal of Travel Research, 16(4), 8-12.

Reisinger, Y. (2009). International tourism: Cultures and behavior. Oxford: Butterworth-Heinemann.

Rohmann, A., Florack, A., \& Piontkowski, U. (2006). The role of discordant acculturation attitudes in perceived threat: An analysis of host and immigrant attitudes in Germany. International Journal of Intercultural Relations, 30(6), 683-702.

Sabates, R., \& Pettirino, F. (2007). The identity of emigrants from Mexico City. Papeles de Población, 52, 211-229.

Sandiford, P. J., \& Seymour, D. (2007). A discussion of qualitative data analysis in hospitality research with examples from an ethnography of English public houses. Hospitality Management, 26(3), 724 742.

SECTUR. (2014). Agendas de competitividad de los destinos turísticos de México. Huatulco, Oaxaca [Mexico's tourism destination competitiveness agenda. Huatulco, Oaxaca]. Mexico: SECTURUMAR. 
SECTUR. (2016). Resultados de la actividad hotelera diciembre 2015 [Hotel activity results December 2015]. Retrieved July 31, 2016, from http://www.datatur.sectur.gob.mx/Documentos20Publicaci ones/2015-12_Reporte20Diciembre.PDF

Sharpley, R. (2014). Host perceptions of tourism: A review of the research. Tourism Management, 42 (1), 37-49.

Sheldon, P., \& Var, T. (1984). Resident attitudes to tourism in North Wales. Tourism Management, 5(1), $40-47$.

Stephan, W. G., \& Stephan, C. W. (2000). An integrated threat theory of prejudice. In S. Oskamp (Ed.), Reducing prejudice and discrimination (pp. 23-45). Mahwah, NJ: Erlbaum.

Stephan, W. G., Ybarra, O., Martínez, C., Schwarzwald, J., \& Tur-Kaspa, M. (1998). Prejudice toward immigrants to Spain and Israel: An integrated threat theory analysis. Journal of Cross-cultural Psychology, 29(4), 559-576.

STyDE. (2015). Indicadores de la actividad turística enero-julio 2015 [January-July 2015 tourism activity indicators]. Retrieved April 16, 2016, from http://www.styde.oaxaca.gob.mx/node/16

Thomason, P., Crompton, J. L., \& Kamp, B. D. (1979). A study of the attitudes of impacted groups within a host community toward prolonged stay tourist visitors. Journal of Travel Research, 17 (3), 2-6.

Trauer, B., \& Ryan, C. (2005). Destination image, romance and place experience - an application of intimacy theory in tourism. Tourism Management, 26(4), 481-491.

Var, T., Kendall, K., \& Tarakcioglu, E. (1985). Resident attitudes towards tourists in a Turkish resort town. Annals of Tourism Research, 12(4), 652-658.

Wang, S., \& Chen, J. (2015). The influence of place identity on perceived tourism impacts. Annals of Tourism Research, 52, 16-28.

Ward, C., \& Berno, T. (2011). Beyond social exchange theory. Attitudes towards tourists. Annals of Tourism Research, 38(4), 1556-1569.

Wilson, T. D. (2012). Economic life of Mexican beach vendors: Acapulco, Puerto Vallarta, and Cabo San Lucas. New York, NY: Lexington Books.

Woods, R. H. (2016). Cognitive dissonance, tourism. In J. Jafari \& H. Xiao (Eds.), Encyclopedia of tourism (pp. 159-160). New York: Springer International Publishing.

Woosnam, K. M. (2011). Testing a model of Durkheim's theory of emotional solidarity among residents of a tourism community. Journal of Travel Research, 50(5), 546-558.

Zhang, J., Inbakaran, R. J., \& Jackson, M. (2006). Understanding community attitudes towards tourism and host-guest interaction in the urban-rural border region. Tourism Geographies, 8(2), 182-204. 